NBER WORKING PAPER SERIES

\title{
EVIDENCE ON THE DETERMINANTS OF THE CHOICE BETWEEN WAGE POSTING AND WAGE BARGAINING
}

\author{
Robert E. Hall \\ Alan B. Krueger \\ Working Paper 16033 \\ http://www.nber.org/papers/w16033
NATIONAL BUREAU OF ECONOMIC RESEARCH
1050 Massachusetts Avenue
Cambridge, MA 02138

May 2010

Hall's research if part of the program on Economic Fluctuations and Growth of the NBER. The opinions stated in this paper are those of the authors alone and not those of the U.S. Treasury or the National Bureau of Economic Research. We are grateful to our discussant John Kennan, to James Malcomson, Guido Menzio, and Giuseppe Moscarini, and to numerous conference participants for helpful comments. A file containing the calculations is available by googling the first author.

NBER working papers are circulated for discussion and comment purposes. They have not been peerreviewed or been subject to the review by the NBER Board of Directors that accompanies official NBER publications.

(C) 2010 by Robert E. Hall and Alan B. Krueger. All rights reserved. Short sections of text, not to exceed two paragraphs, may be quoted without explicit permission provided that full credit, including $\odot$ notice, is given to the source. 
Evidence on the Determinants of the Choice between Wage Posting and Wage Bargaining

Robert E. Hall and Alan B. Krueger

NBER Working Paper No. 16033

May 2010

JEL No. E24,J3,J64

\begin{abstract}
$\underline{\text { ABSTRACT }}$
Some workers bargain with prospective employers before accepting a job. Others face a posted wage as a take-it-or-leave-it opportunity. Theories of wage formation point to substantial differences in labor-market equilibrium between bargained and posted wages. We surveyed a representative sample of U.S. workers to inquire about the wage determination process at the time they were hired into their current or most recent jobs. A third of the respondents reported bargaining over pay before accepting their current jobs. About a third of workers had precise information about pay when they first met with their employers, a sign of wage posting. About 40 percent of workers could have remained on their earlier jobs at the time they accepted their current jobs, indicating a more favorable bargaining position than is held by unemployed job-seekers. Our analysis of the distribution of wages shows that wage dispersion is higher among workers who bargained for their wages. Wages are higher among bargainers than non-bargainers, after adjusting for the differing compositions of the groups. Our results on wages give substantial support to the job-ladder model--workers who had the option to remain at their earlier jobs when they took their current jobs can earn higher wages than those without that option.
\end{abstract}

Robert E. Hall

Hoover Institution

Stanford University

Stanford, CA 94305-6010

and NBER

rehall@gmail.com

Alan B. Krueger

Industrial Relations Section

Firestone Library

Princeton University

Princeton, NJ 08544

akrueger@princeton.edu

An online appendix is available at:

http://www.nber.org/data-appendix/w16033 


\section{Introduction}

Labor is one of the most heterogeneous products traded in a modern economy. The competitive market for a commodity, where all units are interchangeable and all trade for the same price, could hardly be a worse description of the labor market. No Walrasian auctioneer determines the wage. We study survey evidence on the ways that an employer and a worker determine the wage at the outset of their relationship. Our findings support the predictions of theories of wage determination about the relationship among the level and dispersion of wages, on the one hand, and the incidence of bargaining, on the other hand

The extensive literature on this topic considers two main cases. The first is wage posting. Here an employer defines a job in terms of duties and qualifications, and commits to a wage. If a candidate is found qualified and interested, the employer offers the wage on a take-it-or-leave-it basis. The second is bargaining. The employer makes an initial offer, but the candidate can make a counteroffer for a higher wage, if so inclined. A key difference between the two modes is the employer's commitment not to entertain a counteroffer. To the employer, the advantage of posted wages is that the employer may appropriate a large fraction of the surplus of a match. The disadvantage is that a posted wage precludes a match with a candidate whose reservation wage is higher than the posted wage but whose productivity is even higher. Bargaining with this worker would have gained some of the surplus. Bargaining is in the interest of the employer if qualified workers have heterogeneous skill levels.

In the United States, a small fraction of workers in private employment and a larger fraction in government employment receive pay under the terms of collective bargaining agreements. From the point of view of an individual worker, the resulting wage is posted rather than bargained individually. We identify unionized and government workers in our analysis of the survey data.

In addition to wage posting and bargaining, one could imagine a labor market where employers can commit to ignore counteroffers, on the one hand, but make a custom offer to the applicant rather than offering the same wage to all qualified applicants, on the other hand. This market would encounter the Diamond paradox. An employer would make an offer that just meets a worker's reservation wage. The worker knows that the wage is below the maximum that would be acceptable to the employer, but also knows that the employer will not consider a counteroffer that is below that maximum but better than the employer's 
original offer. The worker will accept the original offer. The only equilibrium in the labor market under these conditions is for workers to earn the bare minimum needed to attract them to the market. Workers would not earn the Ricardian rents that normally make up a substantial fraction of wages. We do not believe that this equilibrium occurs in U.S. labor markets. Most workers, especially men aged 25 to 55, appear to have strong preferences for higher market goods consumption together with the higher market work needed to finance that consumption rather than lower levels of both, a clear sign that they have not been pushed to their participation reservation points.

Wage formation has a central role in the theory of unemployment. A positive level of unemployment is inevitable given the frictions in the labor market-some workers will always be in the process of locating a better use for their services after a decline in their productivity in earlier jobs. The anticipated wage determines the payoff to workers to search for new jobs and to employers to recruit new workers. Some bargaining protocols imply that the bargained wage is insensitive to conditions in the labor market, such as productivity and unemployment - see Hall and Milgrom (2008). In these models, the incentive for employers to recruit new workers falls in times of low productivity. As a result, unemployment is sensitive to driving forces such as productivity; the models can deliver realistic volatility of unemployment. By contrast, in models where employers post wages and adjust them each period to their optimal levels, the response of unemployment to driving forces tends to be small and the observed volatility of unemployment remains unexplained.

Our survey has about 1,400 respondents who took jobs sufficiently recently that we believe that their answers about wage formation at the beginning of the job were reasonably reliable. In addition to many questions about their backgounds, we asked four questions that bear specifically on wage formation. The first determined how much a respondent knew about pay before being interviewed for the job. This question bears on the public nature of the wage in a wage-posting market. The second asked if the wage offer for the current job was take-it-or-leave-it or if bargaining occurred. The third asked if the respondent could have kept an existing job at the time he or she took the current job. The option to keep an existing job is valuable in a bargaining setting. The fourth asked if the employer learned the respondent's earlier pay rate during the evaluation process. This knowledge would improve the employer's expected benefit in a setting with bargaining.

Our results show that both major models of wage formation have important roles in the 
U.S. labor market. We find a fairly high level of knowledge among job-seekers prior to their job interviews, potentially the result, in part, of public wage posting. We confirm that this information is particularly common among union members and those who took government jobs. We document a sharply negative relation between education and precise information about pay — non high-school graduates are almost twice as likely as those with professional education to know prospective pay exactly. Thus wage posting appears to be much more important in the less heterogeneous jobs available to those with less education. We discuss the literature that supports the proposition that wage posting is more likely to appear in equilibrium in a market where workers have more heterogeneous skills within groups defined by observed and verifiable characteristics.

We find that about a third of all workers bargained with their current employers - they did not consider their job offers to be take-it-or-leave-it. Bargaining is more common by minority workers and less common by women. The education gradient for bargaining is remarkably steep, rising from 28 percent for those who did not graduate from high school to 56 percent for those with professional degrees. Individual bargaining is rare for union or government jobs.

The respondents who knew the wage in advance and who understood the wage offer to be take-it-or-leave-it are the most likely to have taken jobs in a market with posted wages. We find that this group is 15 percent of workers if we interpret knowing as knowing exactly the wage when first interviewed by the employer. We find that minorities are somewhat less likely to be in the posted-wage sector and women more likely. Participation in the posted-wage sector falls strongly with education. Union members and government workers are highly likely to hold posted-wage jobs.

We find that about 48 percent of workers could have kept their earlier jobs at the time they were considering their current jobs. A substantial fraction of these workers bargained for the wage on their current jobs; virtually all those in a group we call knowledge workers bargained. We conclude that job-ladder models emphasizing on-the-job search are highly relevant for understanding wage formation and that, for jobs with wage bargaining, the option to stay in the earlier job should have an important influence on the wage bargain. We find that those holding the option earn $\$ 2.07$ more per hour than those who did not have existing jobs to fall back on when they took their current jobs.

Finally, we find that 48 percent of workers reported that their employers had learned their 
pay in their earlier jobs before making the offer that led to the current job. This fraction is slightly higher for jobs where actual wage bargaining occurred. It is about the same in situations where the respondent could have kept an earlier job. The fraction varies only a little among categories of workers.

Our survey contains the standard questions from the Current Population Survey about wage rates. We investigate two aspects of the relation between bargaining and the distribution of wages, conditional on observed characteristics such as education. The first is dispersion. If the distinction between wage posting and bargaining is meaningful, the dispersion of wages among workers who accepted posted wages should be smaller than the dispersion among those who bargained. This prediction holds no matter what factors result

in the choices of employers about the mode of wage determination, but it is all the stronger if bargaining is more common for jobs that attract heterogeneous applicants. The second issue is the level of wages of observationally similar workers whose wages were posted or bargained. Theory suggests that wages resulting from bargaining may be higher than posted wages, on the average, a suggestion that our survey supports.

\section{Theory}

\subsection{Research on wage formation}

Pissarides (2000), Mortensen (2003), and Rogerson, Shimer and Wright (2005) discuss much of the relevant research on wage formation for individual workers. In the brief summary in this section, we will discuss all of the research as if it had originally referred to the labor market, though a number of important papers were actually stated in terms of product markets.

Stigler $(1961,1962)$ launched modern thinking about trade in markets for heterogeneous products. He observed that, in the presence of variation in wages, a job-seeker should sample from the distribution of available wages. The choice of the number of samples balances the benefit of finding a higher wage, where the marginal benefit falls with sample size, against the cost of sampling, which is assumed to be constant. McCall (1970) provided an analytical solution to this problem, based on class notes from Kenneth Arrow. Unemployment depends on the amount of sampling job-seekers find optimal.

Diamond (1971) tackled the problem of equilibrium in a search market. He considered the optimal policy of an employer confronted by searchers who follow the Stigler-McCall 
prescription. He observed that, if all other employers set the same wage, one employer could still hire a random visitor by setting a wage below the common wage, but not so far below as to cause the visitor to incur the cost of visiting another employer. This logic shows that a common wage cannot be an equilibrium in the market, with one exception: the monopsony wage could be an equilibrium, because the employer, though able to get a lower wage, would choose not to, as a wage below the monopsony level would yield a lower profit. Diamond concluded that the only common wage in equilibrium would be the monopsony wage, a proposition known as the Diamond paradox. In a simple model where hours of work for those choosing to participate in the labor market are fixed at a standard level or are fairly inelastically supplied, the monopsony wage is the reservation wage that is just sufficient to induce workers to participate in the labor market. This wage level is the value of some alternative activity available to the job-seeker. If the wages for all jobs for which a worker is qualified are set in the way Diamond contemplated, the only equilibrium common wage leaves the worker indifferent between work and non-work. That is, the common wage deprives the worker of all of the Ricardian rents that we normally associate with the labor market, where the elasticity of supply for most workers is relatively low and the area above the supply curve describing the rents is correspondingly large. The supply curve is perfectly elastic at the indifference point, so the area is zero in the Diamond paradox.

The Diamond paradox rests on a strong assumption: The hapless job-seeker cannot strike back by making a counteroffer. The same logic that permits the employer to make a low offer that is still acceptable applies equally to the job-seeker, whose higher counteroffer could leave the employer better off than not hiring the job-seeker. In the Diamond paradox, the employer has all of the bargaining power. Somehow the employer has the power to disregard a counteroffer. It is an open question whether disregarding a counteroffer is credible. The general standard for credibility is on-the-spot rationality or subgame perfection. There is no general answer as a matter of theory to the question of whether an employer holds all the bargaining power. We regard the wage-formation process that leads to the Diamond paradox as unrealistic, not because we know that it is impossible for an employer to have all the bargaining power, but because we believe that wages are well above the indifference level for many workers.

Butters (1977) responded to Diamond's challenge in a way directly relevant to this paper: In Butters's model, the employer offers the same wage to all job-seekers, but the job-seekers 
differ among themselves with respect to information about other wages, so they have diverse reservation wages. By failing to customize the offer, the employer gives some of the surplus to all but the applicant with a reservation wage equal to the common value of all of the employer's offers. The Diamond paradox arises from a situation where the wage offered to each job-seeker is at the reservation level of that person. Butters launched the posted-wage model that we investigate here. In his model, job-seekers learn randomly about the wages of some but not all jobs. In equilibrium, the distribution of wages does not collapse to a single value. Burdett and Judd (1983) extended Butters's and other formulations and discussed other models that portray heterogeneous reservations wages but a common offered wage. Burdett and Mortensen (1998) developed a complete equilibrium model of the labor market along these lines in which the needed heterogeneity arises from job search by employed workers. Because they retain the option of keeping their current jobs, their reservation wages are equal to their current wages and are above the common reservation wage of unemployed job-seekers. Burdett and Mortensen's paper demonstrated the importance of on-the-job search as a matter of theory. Quantification of its importance has proven difficult, as it rests on the fraction of workers who retain the option to stay on their current jobs as they investigate a possible new job. On-the-job search is easy to define in a model but hard to measure in practice.

Within posted-wage models, there is an interesting question as to the public information about wages. Models of directed search give job-seekers partial or complete information about the terms of employment. The simplest setup of this type, with full information available for free to all job-seekers about all job openings, collapses to perfect competition. Rogerson et al. (2005) discuss models where frictions remain.

The other main branch of individual wage-formation theory attributes more symmetric roles to the job-seeker and employer by assuming that they bargain with each other. Mortensen (1978) and Diamond and Maskin (1979) began this line of thought in the context of the formation of symmetric pairs. Diamond (1982) applied it to the labor market with job-seeker-employer matching and wage formation. The modern canon is Mortensen and Pissarides (1994). This literature generally adopted the Nash wage bargain.

Nash's development of his eponymous bargain does not tell a story about how the bargainers reach their bargain. Alternating-offer bargaining seems to fit the way that bargains are actually made in the labor market and elsewhere. Hall and Milgrom (2008) apply Bin- 
more, Rubinstein and Wolinsky's (1986) version of the alternating-offer bargaining model to the setting of the Mortensen-Pissarides model (the paper also discusses earlier applications of alternating-offer bargaining in the labor market). The convention of the labor market appears to be that the employer makes the first offer, just as the seller in the housing market makes the first offer in the form of an asking price. But the wage offer is not a posted wage - the applicant is free to respond with a counteroffer, just as the potential buyer may offer to pay less than the asking price for a house. The parties continue to exchange offers until the prospective benefit from continuing falls short of the cost of delaying the deal, at which point one side accepts the other's offer and the deal is done.

A key point is that the unique equilibrium of an alternating-offer bargaining process with full information is for the employer to offer an acceptable wage as the first offer-one just at the margin between triggering a counteroffer and not triggering one. Thus with full information, one never observes parties actually making counteroffers. One could easily confuse a posted wage setup with an alternating-offer setup, because in both cases, the employer would say, "The job pays X. Do you accept it?" and the job-seeker would just say yes or no, without a counteroffer.

The Nash bargain gives primacy to the bargainers' outside options. Within the alternatingoffer framework, the outside options are controlling if there is a reasonable probability that an interruption would occur in the exchange of offers, if such an exchange occurred hypothetically (as noted above, an actual exchange is off the equilibrium path). The interruption could take the form of the disappearance of the employment opportunity, the appearance of another employer willing to hire the worker, or the appearance of another worker available to fill the job. Hall and Milgrom (2008) discuss a major difference between alternating-offer bargaining with a low probability of interruption and bargaining with a higher probability (Nash). With Nash, the worker's alternative to accepting the employer's current offer is to re-enter the search process to find another job opening (because the opening under consideration may disappear) or to accept a job with another employer. The value of this alternative depends on the tightness of the labor market - the job-seeker's bargaining position is stronger if the next job prospect is easy to find or if the likelihood of receiving a second offer is higher. By contrast, with alternating-offer bargaining and little likelihood of interruption, the alternative is to delay the formation of the job match. The value of this alternative is not diminished when unemployment is higher. Thus the wage is not as 
sensitive to unemployment. The paper explains why the lower sensitivity helps explain the large increases in unemployment that occur in recessions.

With imperfect information, bargaining models become more complicated and prone to indeterminacy. Hall and Lazear (1984) lay out some of the issues in the setting of individual wage formation. See Ausubel, Cramton and Deneckere (2002) for a survey and Menzio (2007) for an application with individual wage formation. Our survey shows that many job-seekers actively bargain with employers, contrary to the full-information bargaining model, so this is an appropriate area for further development.

Figure 1 summarizes the types of model of wage formation between individuals and employers. At the top we put the issue that divides wage posting from bargaining - can the employer commit not to respond to a counteroffer from a job-seeker or otherwise avoid bargaining? If so, the second issue is whether the employer can make a customized offer to the job-seeker that captures all of the surplus from the match. If so, and if the job-seeker has no opportunities in labor markets where workers share the surplus, workers will be paid only enough to bring them into the labor market and will enjoy no Ricardian rents. This condition is the Diamond paradox. If wage offers are not customized and a force such as onthe-job search causes reasonable heterogeneity in reservation wages among applicants who will be paid the same wage, the employer's choice of that wage will result in a sharing of the surplus by all but those with a reservation wage equal to the wage paid.

The right side of the figure describes wage determination when the employer lacks the ability to disregard counteroffers. In that case, alternating-offer bargaining seems the best way to model the process. If interruptions are likely, the process resembles the Nash bargain, where the outside option is influential. Because the current conditions in the labor market control the value of the outside option, wages are flexible in this case. On the other hand, if the parties perceive that interruptions are unlikely, the costs and benefits of delay in completing the bargaining process control the outcome. Because conditions in the labor market are less influential for these costs and benefits, the resulting wage is less connected to those conditions. The result is a sticky wage and more volatile unemployment. 


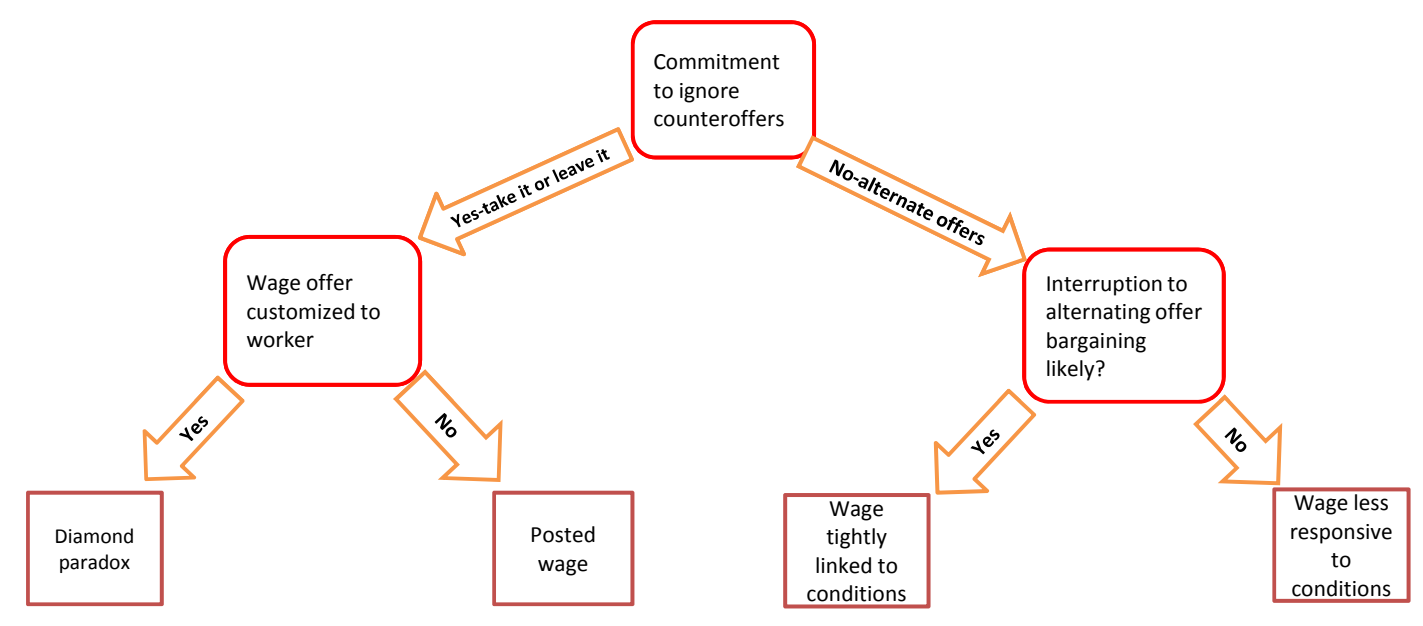

Figure 1: Models of Wage Formation

\subsection{How Would an Employer Decide between Wage Posting and Bargaining?}

We regard the issue of the empirical importance of wage posting - that is, the employer's commitment not to consider counteroffers - as an open question. Commitment may fail the test of on-the-spot rationality, a test often applied in many areas of modern economic analysis. Employers face an issue of time consistency. They might benefit from job-seekers' belief that counteroffers fall on deaf ears, but still occasionally encounter situations where they make no match based on the posted wage, but would gain some of the surplus from the match if they bargained with an applicant. On net, they would choose to sacrifice the benefit of bargaining to gain more of the surplus in the matches they make with wage posting, but cannot stop themselves from giving in to the temptation to consider a counteroffer in the occasional situation where they would gain from it. In some settings of this type, commitment via a trigger strategy may arise. The result is a reputational equilibriumthe employer finds it advantageous to disregard a counteroffer because responding to one would sacrifice the employer's reputation for not considering counteroffers. The reputational equilibrium rests on the notion that job-seekers use trigger strategies - they would switch to making counteroffers to an employer who considered a counteroffer from a single applicant.

An alternative and perhaps more realistic way that employers can commit to disregard counteroffers is to deny managers the power to alter the wage. Such a policy mirrors the 
way that retailers enforce posted prices - the customer cannot find anybody in the store who has the power to accept a price below the posted price.

\subsection{Models of the choice of wage-setting mode}

The most basic model of the employer's choice between posting and bargaining takes the only source of heterogeneity to be dispersion in candidates' reservation wages. Suppose that the distribution of the reservation wage, $z$, is

$$
R(z)=z^{\psi} \text { for } z \in[0,1]
$$

Job-seekers encounter employers randomly, so the parameter $\psi$ is a job-seeker's wage elasticity of labor supply to employers in general and to a particular employer. The profit per job applicant from a strategy of posting a wage $w$ is

$$
(p-w) R(w)
$$

Here $p$ is the worker's productivity. The first-order condition for maximum profit is

$$
w=\frac{\psi}{\psi+1} p
$$

The quantity $\frac{\psi}{\psi+1}$ is the wage mark-down coefficient, analogous to the constant markup coefficient for a firm facing constant elasticity of demand. Profit per applicant under the posting strategy is

$$
\pi_{P}=\frac{\psi^{\psi}}{(\psi+1)^{\psi+1}} p^{\psi+1} .
$$

The profit from a bargaining strategy is a fraction $\beta$, the employer's bargaining power, of the joint surplus from a match, which is the difference between productivity $p$ and the worker's opportunity value $z$. Expected profit is

$$
\beta R(p)(p-\mathbb{E}(z \mid z \leq p))
$$

Here $R(p)$ is the probability that the employer will make a deal with the applicant, the probability that an efficient match is possible, with $z \leq p$. The expectation of $z$ conditional on an efficient match is

$$
\frac{\psi}{\psi+1} p
$$

Thus expected profit per applicant from a bargaining strategy is

$$
\pi_{B}=\frac{\beta}{\psi+1} p^{\psi+1}
$$


Bargaining is the more profitable strategy if

$$
\beta>\left(\frac{\psi}{\psi+1}\right)^{\psi} .
$$

For the benchmark case of unit-elastic labor supply, $\psi=1$, the criterion is that the employer's bargaining power exceed one half. The critical value of $\beta$ approaches 1 as the elasticity approaches zero and approaches $e^{-1}=0.37$ as the elasticity becomes large.

The variance of the reservation wage, $z$, is a hump-shaped function of the elasticity, $\psi$, reaching a maximum at $\psi=0.62$ (for low $\psi$, the density concentrates at $z=0$, with close to zero variance; for high $\psi$, at 1 , again with small variance). Over the range from $\psi=0$ to 0.62 , dispersion of the reservation wage rises with $\psi$ and the likelihood of bargaining rises as well, in the sense that the critical bargaining power $\beta$ falls. In this range, greater heterogeneity among job applicants inclines employers further toward bargaining rather than posting. But the relationship reverses for higher elasticities. The assumption that the distribution of reservation wages differs among groups only in its elasticity and not in its position is essentially arbitrary, however. If the distribution takes the form

$$
R(z)=\left(\frac{z}{\gamma}\right)^{\psi} \text { for } z \in[0, \gamma]
$$

and the position parameter $\gamma$ is higher among groups with higher elasticity, the relation between the variance and the critical value of bargaining power would be negative over a wider range of values.

Under posting, all workers who accept the posted wage earn that wage, $w=\frac{\psi}{\psi+1} p$, so dispersion is zero. A worker with reservation wage $z \leq p$ who takes a job with a bargaining employer earns a wage of

$$
\beta z+(1-\beta) p
$$

The expected wage, conditional on employment, is

$$
\beta \frac{\psi}{\psi+1} p+(1-\beta) p
$$

which is unambiguously greater than the posted wage. In a comparison of wage levels between workers who accepted jobs with posted wages and those who bargained for their wages, we would expect to find higher average wages in the second group. Again, this statement is based on the essentially arbitrary assumption that the only difference between 
the two groups was in the elasticity of the wage distribution. If the position parameter $\gamma$ is positively associated with the elasticity, then the effect would be even larger.

Our survey measures the dispersion of actual wages. Thus we expect to find lower wage dispersion among workers who accepted posted wages than among those who bargained, quite apart from any differences in dispersion of reservation wages or other unobserved variables. Our empirical investigation of wage dispersion in relation to posting and bargaining is intended more to test the validity of our survey question than to provide evidence about dispersion in those unobserved characteristics.

Ellingsen and Rosén (2003) investigate dispersion in skills rather than reservation wages within observationally identical workers. They build a model along the lines of Mortensen and Pissarides (1994) in which employers decide prior to meeting job-seekers whether to stick to a posted wage or to bargain. They do not mention the obstacles to enforcing a policy of not bargaining; they take its credibility for granted and model the choice in terms of the maximal payoff to the employer. Heterogeneity in applicants is central to the analysis - if all workers had the same skills and same non-market value of time, the employer would be choosing between Nash bargaining with given division of the surplus against making a take-it-or-leave-it offer to the applicant, which is simply Nash bargaining with all bargaining power on the employer's side. Obviously the employer chooses the posted wage. The authors show that heterogeneity above a critical level makes it possible for bargaining to occur in an equilibrium. In a bargaining equilibrium, the advantage to the employer of customizing the wage through negotiation outweighs the reduction in the bargaining power of the employercapturing some of the surplus in all efficient matches yields a higher return to the employer than capturing all of the surplus in a fraction of the efficient matches. Their model does not rule out other equilibriums with wage posting. In particular, because they assume that the non-market alternative for all workers has the same value, the Diamond equilibrium, where all employers post that value as the offered wage, is an equilibrium. Michelacci and Suarez (2006) study a directed search setup where job-seekers have a role in the choice between wage posting and bargaining.

These two papers confirm the intuition that heterogeneity in skills may have a role in the choice between posting and bargaining. The heterogeneity that matters is within categories defined by verifiable characteristics of job-seekers - employers can post wages conditional on anything verifiable. Michelacci and Suarez discuss this point. 


\subsection{Why the choice between posting and bargaining matters}

The amount of rent that employers earn from the employment relationship has a central role in models of unemployment fluctuations. Most models assign the employer the task of deploying resources to generate job matches, which seems realistic, though we are not aware of any systematic evidence on the subject. Matchmakers in the labor market, both on and off the Internet, typically impose the great bulk of their charges on the employer.

The rent that employers earn in the employment relationship arises from frictions in the labor market. When setting a wage for a job-seeker who has overcome the friction and found a willing employer, the employer has an advantage because the job-seeker will anticipate encountering similar friction in finding the next opportunity if the job-seeker rejects the one in hand. Absent the friction, the job-seeker could work one employer against another until the wage rose to the level of productivity. Because the employer gains from forming the relationship, the employer has an incentive to deploy resources to attract job-seekers.

Variations in the rents that employers earn generate corresponding variations in the recruiting efforts of employers. When rent is high, employers expand vacancy posting and other recruiting activities and thus tighten the labor market, lowering unemployment. The rent is the present value of the difference between a newly hired worker's productivity and the wage paid to the worker. If productivity rises and the wage remains constant or rises less than productivity, the rent increases and the labor market tightens. If the wage tracks productivity, labor-market tightness and unemployment remain constant.

Models of posted wages generally make the assumption of directed search - job-seekers learn the posted wages of all employers, along with other terms of employment, and pick the best available job. Rogerson and Shimer (2012, forthcoming), a handbook article on job-search economics, describes this research:

A number of papers assume that firms post wages offers and workers can direct their search towards their preferred offer, as in the competitive search literature [citations omitted]. The equilibrium of that model coincides with the social planners solution, and so wages are flexible. Models of wage rigidities therefore typically assume either that firms cannot commit to wages or that workers cannot direct their search. (footnote 31, page 41)

Although the assumption of a posted wage in a model with random search would not be 
unreasonable, apart from the commitment issue, that combination has not appeared in the literature, to our knowledge. Random search is paired with bargaining.

In posted-wage models where employers reset their posted wages each period, the wages are flexible and respond fully to driving forces such as changes in productivity. Equation (3) shows that, in the constant-elastic case, the posted wage is proportional to productivity. Equation (11) shows that, in the same case, the expected wage resulting from bargaining is also proportional to productivity, provided the bargaining power of the employer, $\beta$, is constant. As a result, labor-market models with Nash bargaining generally deliver little or no volatility of unemployment. Shimer (2010) discusses this point in detail, including the exceptions to the general rule.

In bargaining models where the employer's share is an endogenous variable rather than a constant, unemployment volatility can be substantial. The direction of the movement of the share may appear counter-intuitive - the employer's share needs to rise in good times with low unemployment and fall in bad times with high unemployment. To put it differently, wages need to be sticky and respond less than fully to driving forces such as productivity. Hall (2005) discusses this point without introducing a specific bargaining protocol, while Hall and Milgrom (2008) show that alternating-offer bargaining with a low but realistic frequency of interruption delivers the needed endogenous shifts of the employer's share of the surplus.

We conclude that a finding that a substantial majority of jobs were filled at posted wages would be unfavorable for an important branch of modern thinking about unemployment volatility.

The New Keynesian branch of modern thinking, by contrast, presumes posted wages, but does not characterize employers' wage-setting as maximizing the expected benefit from current hiring, along the lines of the simple model we presented earlier in this section. The canon of New Keynesian economics, Christiano, Eichenbaum and Evans (2005), makes the assumption that workers post wages. Further, a worker does not set the posted wage to its optimal level each period, but only at random intervals, with a probability of re-optimization of 36 percent per calendar quarter. During spells without re-optimization, the worker supplies the amount of work that the employer chooses, given the predetermined wage. The model does not describe unemployment explicitly, but achieves realistic volatility of total hours of work because of the time it takes for a significant fraction of workers to adjust their wages to a change in demand. Prior to full adjustment, employment (hours of work) is sensitive to 
demand because of the imperfect adjustment of the wage in the shorter run.

Our survey did not inquire if workers thought they could unilaterally set their own wages. We doubt that any of our respondents would be that presumptive. Christiano and co-authors use the assumption for convenience, not reality. The key assumptions of the New Keynesian model are that the wage is fixed for a significant period and that during the period, the employer chooses the level of labor input. Whether the worker or the employer sets the wage when it is re-optimized affects the level of the wage but not the volatility of employment induced by persistent wage stickiness. Thus our finding that an important fraction of wages are posted gives some support to the posting element of the New Keynesian model, but does not bear on the question of persistent stickiness of the wage or on the idea that the employer chooses labor input unilaterally.

\section{Objectives of the Survey}

We designed our survey to provide evidence on the facts underpinning the two leading types of models of individual wage formation. The most obvious area of investigation is whether employers post wages which, to the individual, are take-it-or-leave-it offers, as opposed to engaging in any type of bargaining. We address this directly by asking if respondents perceived the wage as take-it-or-leave-it, on the one hand, or if they bargained, on the other hand. In formulating this question we were quite aware that there was an omitted intermediate case, that, while the offer was not take-it-or-leave-it, the respondent did not believe that it would be worth the effort to make a counteroffer. We regarded this as beyond the reach of our survey techniques, though this issue is ripe for reconsideration in future work.

A second objective is to probe for information known in advance about the wage a job paid. In the directed search model, respondents would have known the wage before sinking any cost in applying for a job. In addition, we regard advance knowledge of the wage as evidence of wage posting. We used two standards for assessing this knowledge: we asked if the respondent knew the pay exactly and if the respondent had a pretty good idea. A large fraction of the respondents picked the "pretty good idea" answer, so future work might benefit from an intermediate phrasing.

A third objective is to measure the incidence of on-the-job search. Previous work, such as Moscarini and Postel-Vinay (2008), has tried to answer this question from data on job flows, but the evidence from that source is at best indirect because it does not report on the 
issue of the option to keep the current job that is so central in wage formation theory. Also, earlier work measures the fraction of hires that came directly from other jobs while in this paper we measure the fraction of workers with tenure less than 10 years who retained the option to remain on an earlier job when they were hired.

A fourth objective is to study the information that employers have about a prospect's current or recent wage. This information has a key role in bargaining, especially when the prospect has the option of keeping the job rather than taking a new job with the employer. Of course, in a survey of workers, we are limited to inquiring about what the worker thinks the employer knew when the worker was hired.

\section{Survey Design}

Our survey is part of the Princeton Data Improvement Initiative, a project to develop new questions for labor force surveys. The questionnaire was patterned after the Current Population Survey and included questions on career experience, job tasks, and occupational licensing. We designed a module to assess the prevalence of wage posting and employer-employee bargaining at the time employees were hired. Based on a focus group, we concluded that individuals who were hired within the past 10 years could recall how knowledgeable they were about the pay on their job when they first interviewed for it, whether the employer made a take-it-or-leave-it offer, whether they could have remained on their previous job if they had wanted to, and whether their employer was aware of their pay on their previous job prior to making them an offer. Those who were employed at the time of the survey were asked about their current job (87 percent), and those who were unemployed at the time of the survey were asked about their last jobs (13 percent). The unemployment rate for the (weighted) sample as a whole was 5.3 percent.

The survey organization Westat conducted the survey from June 5 to July 20, 2008. Individuals age 18 or older who were in the labor force were eligible for the survey. A total of 2,513 individuals were interviewed, 1,435 of whom were hired in the previous 10 years. Westat used a random-digit-dial sampling design constructed from a national sampling frame of residential exchanges. The selected numbers were then called and screened to identify households with eligible respondents. One respondent was randomly selected from each eligible household for the interview using the nearest birthday procedure. Up to 15 callbacks were made to try to elicit responses. Some 28 percent of sampled eligible households 
agreed to participate in the screening questions, and 64 percent of the selected individuals in screened households completed the questionnaire. Thus the response rate was 17.9 percent, using the American Association for Public Opinion Research response rate definition 3 (see aapor.org/uploads/Standard_Definitions_04_08_Final.pdf, p. 35).

Westat developed survey weights to compensate for variation in selection probabilities, differential response rates, and possible under-coverage of the sampling frame. The derivation of the sample weights focused primarily on matching the marginal distributions of the Current Population Survey by sex, age, educational attainment, census region, urbanization, race, Hispanic ethnicity, employment status, and class of employer (private, government, etc.). See irs.princeton.edu/PDIIMAIN.htm for a detailed description of the derivation of the sample weights and the questionnaire.

Although the survey response rate is low compared to many government labor force surveys, it is comparable to that in commercial surveys. Groves and Peytcheva (2008) show that survey non-response rates by themselves are not associated with significant bias. Low response rates are a concern when the causes of participation in the survey are correlated with the survey variables of interest. We do not believe that wage-formation practices from years earlier would be correlated with survey participation. The response rate was low in large part because many households declined to participate in the screener questions, which did not mention wages or job search at all. Another reason for placing some confidence in the representativeness of our sample is that a standard Mincerian wage regression using data from the survey closely matched the corresponding regression from the Current Population Survey. Although we would have preferred a higher response rate, we have no reason to believe that non-response skews our results in favor or against any particular wage formation model

\section{$5 \quad$ Findings}

\section{$5.1 \quad$ Descriptive logit model}

To describe our survey findings, we use a logit probability model for yes-no variables constructed from the respondents' answers. The model predicts the probability of a yes answer, given a set of variables describing the individual and the job. These variables are

- Indicator for African-American individual 
- Indicator for Latino or Latina individual

- Indicator for a woman

- A set of indicators for education, in five categories

- Indicator for union membership

- A set of indicators for private, government, and non-profit employer

- Work experience in years

- Age in years

- Tenure in years

- Indicator for repetitive job

- Indicator for physical job

- Indicator for job involving managing

- Indicator for job involving problem solving

- Indicator for job involving use of math

- Indicator for job involving reading long documents frequently

Table 1 summarizes the composition of the survey respondents.

We use a weighted logit estimator because the purpose of estimation is to describe the responses, not estimate underlying parameters. We use the resulting logit model to make statements about responses in different subsets of the population. We present the results in terms of the estimated probability of a yes answer for a variety of types of workers, along with bootstrap standard errors of the probabilities and of the differences between the probability for a group and the probability for a base case. The online backup materials for this paper include the underlying logit estimates.

Our base case is: individual not African-American, not Latino or Latina, a man, highschool education but no college, not a union member, working for a private employer, 40 years old, 20 years of experience, 4 years of tenure, and none of the specific job characteristics listed above. We display the results as probabilities of a yes answer for a variety of groups 


\begin{tabular}{lc}
\hline \hline Category or characteristic & Percent or average \\
\hline African-American & 10 \\
Latino/a & 15 \\
Woman & 46 \\
Education & \\
Not HS graduate & 9 \\
Some college & 25 \\
College graduate & 22 \\
Professional training & 13 \\
Union member & 17 \\
Government job & 17 \\
Non-profit job & 11 \\
Years of work experience & 18 \\
Age & 41 \\
Currently employed & 88 \\
Lost job in past 3 years & 13 \\
Years with this employer & 7 \\
Repetitive activities & 50 \\
Physical activity & 57 \\
Managing or supervising & 29 \\
Solving problems & 71 \\
Use of advanced math & 26 \\
Reading long documents & 17 \\
\hline \hline
\end{tabular}

Table 1: Survey Respondents 
defined by the right-hand variables. In addition to groups defined by a single indicator, such as for women, we include four groups defined by combinations of right-hand variables (variables not mentioned in this list are the same as in the base case):

- Senior: 40 years of experience, 60 years old, 30 years tenure, job involves managing

- Knowledge worker: post-college education, 20 years of experience, 60 years old, 30 years tenure, job involves solving problems, using advanced math, and reading long documents

- Blue collar: union member, 20 years of experience, 40 years old, 10 years tenure, job involves physical and repetitive tasks

- Recent job loser: 20 years of experience, 40 years old, one year of tenure, job involves none of the specific characteristics

\subsection{Evidence about the relative importance of wage posting and bargaining}

Table 2 summarizes the responses to the question, "When you were offered your (current/previous job), did your employer make a 'take-it-or leave-it' offer or was there some bargaining that took place over the pay?" The table describes the probability that a respondent would answer that some bargaining occurred. A respondent with the base characteristics has a probability of 31 percent of that response. As we discussed earlier, the absence of bargaining implied by that response does not necessarily mean that the respondent believed that the employer was committed to the wage offer and would not have entertained a counteroffer. In an alternating-offer equilibrium, the job-seeker can make a counteroffer and the employer would consider it, but the job-seeker never does, because the original offer was made with that possibility in mind and was high enough to make a counteroffer not worth the effort. Thus, in some ways, it is a surprise that 31 percent in the base group replied that some bargaining did take place. The observed incidence of bargaining arises from departures from the assumptions of the full-information alternating-offer bargaining game. The departures could include private information, potentially on both sides, and biased assessments of worker and job characteristics.

The frequency of no-bargaining responses varies substantially among job-seekers. It is higher than the base-case level among African-Americans (43 percent) and Hispanics (44 


\begin{tabular}{|c|c|c|}
\hline & \multicolumn{2}{|c|}{$\begin{array}{c}\text { Based on response, some } \\
\text { bargaining took place }\end{array}$} \\
\hline & $\begin{array}{c}\text { Probability of } \\
\text { bargaining, } \\
\text { percent }\end{array}$ & $\begin{array}{c}\text { Difference } \\
\text { from base } \\
\text { case }\end{array}$ \\
\hline Base case & $\begin{array}{l}31 \\
(7)\end{array}$ & \\
\hline African-American & $\begin{array}{c}43 \\
(11)\end{array}$ & $\begin{array}{l}11 \\
(9)\end{array}$ \\
\hline Latino/a & $\begin{array}{c}44 \\
(10)\end{array}$ & $\begin{array}{l}12 \\
(7)\end{array}$ \\
\hline Woman & $\begin{array}{l}24 \\
(6)\end{array}$ & $\begin{array}{l}-8 \\
(4)\end{array}$ \\
\hline Not HS graduate & $\begin{array}{c}28 \\
(10)\end{array}$ & $\begin{array}{l}-3 \\
(9)\end{array}$ \\
\hline Some college & $\begin{array}{l}40 \\
(8)\end{array}$ & $\begin{array}{c}9 \\
(6)\end{array}$ \\
\hline College graduate & $\begin{array}{l}42 \\
(7)\end{array}$ & $\begin{array}{l}11 \\
(6)\end{array}$ \\
\hline Professional training & $\begin{array}{l}56 \\
(7)\end{array}$ & $\begin{array}{l}25 \\
(7)\end{array}$ \\
\hline Union member & $\begin{array}{l}14 \\
(5)\end{array}$ & $\begin{array}{l}-18 \\
(5)\end{array}$ \\
\hline Government job & $\begin{array}{l}16 \\
(6)\end{array}$ & $\begin{array}{l}-15 \\
(5)\end{array}$ \\
\hline Non-profit job & $\begin{array}{l}25 \\
(7)\end{array}$ & $\begin{array}{l}-7 \\
(4)\end{array}$ \\
\hline Senior & $\begin{array}{c}43 \\
(18)\end{array}$ & $\begin{array}{c}12 \\
(16)\end{array}$ \\
\hline Knowledge worker & $\begin{array}{l}86 \\
(4)\end{array}$ & $\begin{array}{l}55 \\
(7)\end{array}$ \\
\hline Blue collar & $\begin{array}{c}5 \\
(2)\end{array}$ & $\begin{array}{l}-26 \\
(7)\end{array}$ \\
\hline Recent job loser & $\begin{array}{l}32 \\
(7)\end{array}$ & $\begin{array}{c}0 \\
(2)\end{array}$ \\
\hline
\end{tabular}

Note: Bootstrap standard errors in parentheses.

Table 2: Probability that Some Bargaining Occurred over Pay 
percent). Women, at 24 percent, are rather less likely than the men in the base case to bargain. The incidence of wage bargaining rises dramatically with education. Respondents with professional education had a probability of 56 percent of a bargaining during hiring. Finally, and not surprisingly, union members (14 percent) and government workers (16 percent) had low propensities to report bargaining over pay. Our other cases show dramatic variation in the incidence of bargaining. Knowledge workers, at 86 percent, almost all reported bargaining, whereas blue-collar workers, at 5 percent, almost never bargain. Senior workers, at 43 percent, are in the middle.

Table 3 describes the answers to the question, "At the time that you were first interviewed for your job, did you already know exactly how much it would pay, have a pretty good idea of how much it would pay, or have very little idea of how much it would pay if you got it?" We consider the probability of the answer that the respondent knew exactly how much it would pay. We believe that this answer would be chosen by individuals who had applied for a job after seeing a formal description that included a committed rate of pay. We do not show the results for the group who responded that they knew exactly or had a pretty good idea, because the responses for all groups were high - uniformly above 80 percent. It would have been useful for the survey to include another response somewhere between "exactly" and "pretty good idea."

In the base case, 22 percent of the respondents in the base group reported that they knew exactly how much the job paid before the employer learned about the respondent. The weighted unconditional sample mean is 31 percent. The difference arises from the fact that the base group is not representative of the entire sample.

On its face, this evidence suggests that nearly a third of jobs involve posted wages. We do not push this interpretation too far, because, on the one hand, another 65 percent of the respondents in the base group said they had a pretty good idea of what the job would pay, and, on the other hand, job-seekers could know the wage even if it were not a committed, posted wage. In standard bargaining models with no private information, the worker knows in advance what wage will result from bargaining.

The table shows that an African-American worker otherwise in the base group has a somewhat lower likelihood, 21 percent, of knowing the pay in advance, while a Latino or Latina has an even lower likelihood, 17 percent. Women have the same likelihood as men. The probability of knowing pay in advance falls substantially with education. Union members 


\begin{tabular}{|c|c|c|}
\hline & \multicolumn{2}{|c|}{$\begin{array}{l}\text { Worker knew pay exactly } \\
\text { prior to interview }\end{array}$} \\
\hline & $\begin{array}{c}\text { Probability, } \\
\text { percent }\end{array}$ & $\begin{array}{c}\text { Difference } \\
\text { from base } \\
\text { case }\end{array}$ \\
\hline Base case & $\begin{array}{l}22 \\
(5)\end{array}$ & \\
\hline African-American & $\begin{array}{l}21 \\
(8)\end{array}$ & $\begin{array}{l}-2 \\
(6)\end{array}$ \\
\hline Latino/a & $\begin{array}{l}17 \\
(6)\end{array}$ & $\begin{array}{l}-6 \\
(5)\end{array}$ \\
\hline Woman & $\begin{array}{l}22 \\
(5)\end{array}$ & $\begin{array}{c}0 \\
(3)\end{array}$ \\
\hline Not HS graduate & $\begin{array}{l}20 \\
(7)\end{array}$ & $\begin{array}{l}-2 \\
(6)\end{array}$ \\
\hline Some college & $\begin{array}{l}20 \\
(5)\end{array}$ & $\begin{array}{l}-3 \\
(4)\end{array}$ \\
\hline College graduate & $\begin{array}{l}15 \\
(4)\end{array}$ & $\begin{array}{l}-8 \\
(4)\end{array}$ \\
\hline Professional training & $\begin{array}{l}14 \\
(4)\end{array}$ & $\begin{array}{l}-8 \\
(5)\end{array}$ \\
\hline Union member & $\begin{array}{l}36 \\
(8)\end{array}$ & $\begin{array}{l}13 \\
(6)\end{array}$ \\
\hline Government job & $\begin{array}{l}36 \\
(8)\end{array}$ & $\begin{array}{l}14 \\
(6)\end{array}$ \\
\hline Non-profit job & $\begin{array}{l}27 \\
(7)\end{array}$ & $\begin{array}{c}4 \\
(4)\end{array}$ \\
\hline Senior & $\begin{array}{c}53 \\
(17)\end{array}$ & $\begin{array}{l}30 \\
(16)\end{array}$ \\
\hline Knowledge worker & $\begin{array}{l}17 \\
(4)\end{array}$ & $\begin{array}{l}-6 \\
(6)\end{array}$ \\
\hline Blue collar & $\begin{array}{l}56 \\
(8)\end{array}$ & $\begin{array}{l}33 \\
(8)\end{array}$ \\
\hline Recent job loser & $\begin{array}{l}20 \\
(5)\end{array}$ & $\begin{array}{l}-2 \\
(1)\end{array}$ \\
\hline
\end{tabular}

Note: Bootstrap standard errors in parentheses.

Table 3: Probability of Knowing What the Job Would Pay 
and those who took government jobs report knowing the wage exactly with substantially higher frequency. Except for a reversal of the pattern of education effects, the differences among respondents captured by the variables are similar. Apparently the most educated workers are the least likely to admit they were clueless about pay when they applied for a job.

Do employers determine and post wages prior to screening workers or do they make an offer to a worker after screening that is, in principle, negotiable via a counteroffer? No single question in the survey answers this important question. The results above showed that about a third of workers know wages exactly prior to their interviews and that about two-thirds viewed their pay offer as having a take-it-or-leave-it character. The left panel of Table 4 describes the respondents who said they knew the pay exactly prior to being interviewed and that there was no bargaining over pay. The likelihood that a base-case respondent gave these two answers is 15 percent. As an estimate of the fraction of workers whose wages were posted, this estimate has biases in both directions. It is an underestimate if workers felt they did not know the pay exactly, even though they were well informed. It is an overestimate on account of workers who anticipated how bargaining would later come out, but received a customized wage influenced by the employer's inability to disregard a jobseeker's counteroffer. The essence of the posted-wage model is the employer's commitment to disregard counteroffers.

Table 4 shows large variations across categories of workers in the estimated incidence of wage posting based on the criterion of knowing the wage in advance and not engaging in bargaining. African-Americans and Hispanics face slightly lower likelihoods, at 12 percent and 10 percent. Women are higher than the base value, at 17 percent. The incidence of wage posting declines dramatically with education, from 12 percent for those who did not complete high school to 5 percent for those with professional training. The higher incidence of wage posting for the least educated is consistent with the view that a wage constrained by the minimum wage is inherently posted. Somewhat more than 10 percent of the respondents earned the minimum wage.

At 28 percent, wage posting is far more common for union members. Similarly, government jobs, at 31 percent, are substantially more likely to have posted pay, compared to the base case. The logit coefficients in the right-hand panel are generally similar to those in the left-hand panel. Most of the difference comes from the much higher constant for the more 


\begin{tabular}{cc}
\hline \hline $\begin{array}{c}\text { Response: knew wage exactly } \\
\text { and wage was take-it-or-leave- } \\
\text { it }\end{array}$ \\
\hline $\begin{array}{c}\text { Probability, } \\
\text { percent }\end{array}$ & $\begin{array}{c}\text { Difference } \\
\text { from base } \\
\text { case }\end{array}$ \\
\hline
\end{tabular}

Base case

15

(4)

(6) (4)

Latino/a $\quad 10 \quad-5$

(4) (4)

Woman $17 \quad 3$

(5) (3)

Not HS graduate 12

$12-3$

(6) (6)

Some college $\quad 12 \quad-3$

(4) (3)

$\begin{array}{lll}\text { College graduate } & 9 & -6\end{array}$

(3) (3)

Professional training 5

(2) (4)

Union member $\quad 28 \quad 13$

(7) (5)

$\begin{array}{lll}\text { Government job } & 31 & 16\end{array}$

(9) (6)

$\begin{array}{lll}\text { Non-profit job } & 22 & 7\end{array}$

(7) (5)

$\begin{array}{lll}\text { Senior } & 27 & 13\end{array}$

(17) (16)

$\begin{array}{lll}\text { Knowledge worker } & 4 & -10\end{array}$

(1) (4)

Blue collar $\quad 50 \quad 36$

(9) (10)

Recent job loser $\quad 13 \quad-2$

(4) (1)

Bootstrap standard errors in parentheses.

Table 4: Probability of Wage Posting 
inclusive criterion, so the probabilities on the right are roughly proportionally higher than those on the left.

Table 4 indicates a higher incidence of wage posting in the more standardized jobs available to those who have not graduated from college and the lower incidence among college graduates and those with professional education. The highest probability of posting in the table is 50 percent for blue collar workers and the lowest is 4 percent for knowledge workers.

\subsection{Evidence about factors that influence bargaining}

Table 5 summarizes the responses to the question, "Think back to the time when you were offered your (current/most recent) job. When you were offered this job, was it possible for you to keep your previous job instead if you wanted to?" Our interest in this topic derives from the value of the option to keep a current job in a bargaining setting. The sample includes those who were not employed immediately prior to obtaining their most recent job (coded as unable to keep their previous job). The left panel describes the answers among all respondents and the right panel reports the frequency of bargaining over pay among those who could have kept the previous job at the time they accepted the current job.

Among all respondents, in the left-hand panel, the table shows that an individual in the base category had a 48 percent chance of answering yes. Thus almost half of job-seekers has the bargaining advantage of the option of keeping an existing job. Variations from the base-case probability of retaining a previous job are relatively small, according to the table. Minority members are slightly more likely to retain the option and women slightly less likely. The likelihood of the option is a bit lower for the least educated and a bit higher for college graduates, though just the same as in the base case for those with graduate training. Union members are also slightly more likely to have the option of keeping an existing job. Note that the fractions of job-seekers with the option are necessarily higher than the figure in the table - our data omit instances in which employed job-seekers decided that a new job was not as desirable as their existing job and therefore remained at the job despite finding another employment opportunity. Our survey focused on the beginning of the current or most recent job and did not inquire about job offers received in the course of that job.

The incidence of actual bargaining among those who could have kept their previous jobs varies tremendously. In the base case, 45 percent bargained, rather higher than the 31 percent in Table 2 for all workers. Among workers in the senior group who could have 


\begin{tabular}{|c|c|c|c|c|}
\hline & \multicolumn{2}{|c|}{ Could have kept earlier job } & \multicolumn{2}{|c|}{$\begin{array}{c}\text { Among those who could have } \\
\text { kept earlier job, some } \\
\text { bargaining occurred }\end{array}$} \\
\hline & $\begin{array}{c}\text { Probability, } \\
\text { percent }\end{array}$ & $\begin{array}{l}\text { Difference } \\
\text { from base } \\
\text { case }\end{array}$ & $\begin{array}{c}\text { Probability, } \\
\text { percent }\end{array}$ & $\begin{array}{l}\text { Difference } \\
\text { from base } \\
\text { case }\end{array}$ \\
\hline Base case & $\begin{array}{l}48 \\
(7)\end{array}$ & & $\begin{array}{c}45 \\
(13)\end{array}$ & \\
\hline African-American & $\begin{array}{c}54 \\
(10)\end{array}$ & $\begin{array}{c}7 \\
(8)\end{array}$ & $\begin{array}{c}66 \\
(14)\end{array}$ & $\begin{array}{c}22 \\
(11)\end{array}$ \\
\hline Latino/a & $\begin{array}{l}50 \\
(9)\end{array}$ & $\begin{array}{c}3 \\
(6)\end{array}$ & $\begin{array}{c}69 \\
(16)\end{array}$ & $\begin{array}{c}25 \\
(10)\end{array}$ \\
\hline Woman & $\begin{array}{l}46 \\
(7)\end{array}$ & $\begin{array}{l}-1 \\
(4)\end{array}$ & $\begin{array}{c}37 \\
(13)\end{array}$ & $\begin{array}{l}-8 \\
(8)\end{array}$ \\
\hline Not HS graduate & $\begin{array}{c}49 \\
(10)\end{array}$ & $\begin{array}{c}1 \\
(9)\end{array}$ & $\begin{array}{c}38 \\
(15)\end{array}$ & $\begin{array}{c}-7 \\
(16)\end{array}$ \\
\hline Some college & $\begin{array}{l}50 \\
(7)\end{array}$ & $\begin{array}{c}2 \\
(6)\end{array}$ & $\begin{array}{c}62 \\
(13)\end{array}$ & $\begin{array}{c}17 \\
(10)\end{array}$ \\
\hline College graduate & $\begin{array}{l}48 \\
(6)\end{array}$ & $\begin{array}{c}1 \\
(6)\end{array}$ & $\begin{array}{c}64 \\
(11)\end{array}$ & $\begin{array}{c}20 \\
(10)\end{array}$ \\
\hline Professional training & $\begin{array}{l}40 \\
(7)\end{array}$ & $\begin{array}{l}-7 \\
(6)\end{array}$ & $\begin{array}{l}83 \\
(8)\end{array}$ & $\begin{array}{c}38 \\
(11)\end{array}$ \\
\hline Union member & $\begin{array}{l}56 \\
(9)\end{array}$ & $\begin{array}{c}8 \\
(6)\end{array}$ & $\begin{array}{l}10 \\
(6)\end{array}$ & $\begin{array}{l}-35 \\
(9)\end{array}$ \\
\hline Government job & $\begin{array}{l}43 \\
(9)\end{array}$ & $\begin{array}{c}-5 \\
(6)\end{array}$ & $\begin{array}{c}27 \\
(12)\end{array}$ & $\begin{array}{l}-18 \\
(10)\end{array}$ \\
\hline Non-profit job & $\begin{array}{l}46 \\
(9)\end{array}$ & $\begin{array}{l}-2 \\
(7)\end{array}$ & $\begin{array}{c}48 \\
(16)\end{array}$ & $\begin{array}{c}3 \\
(10)\end{array}$ \\
\hline Senior & $\begin{array}{c}42 \\
(16)\end{array}$ & $\begin{array}{c}-6 \\
(15)\end{array}$ & $\begin{array}{c}78 \\
(21)\end{array}$ & $\begin{array}{c}33 \\
(19)\end{array}$ \\
\hline Knowledge worker & $\begin{array}{l}48 \\
(8)\end{array}$ & $\begin{array}{c}0 \\
(9)\end{array}$ & $\begin{array}{l}90 \\
(4)\end{array}$ & $\begin{array}{c}45 \\
(13)\end{array}$ \\
\hline Blue collar & $\begin{array}{l}48 \\
(9)\end{array}$ & $\begin{array}{c}0 \\
(9)\end{array}$ & $\begin{array}{c}3 \\
(2)\end{array}$ & $\begin{array}{c}-42 \\
(12)\end{array}$ \\
\hline Recent job loser & $\begin{array}{l}49 \\
(8)\end{array}$ & $\begin{array}{c}1 \\
(2)\end{array}$ & $\begin{array}{c}44 \\
(13)\end{array}$ & $\begin{array}{l}-1 \\
(3)\end{array}$ \\
\hline
\end{tabular}

Note: Bootstrap standard errors in parentheses.

Table 5: Probability that the Previous Job Could Have Been Kept 
kept their jobs, 78 bargained, also well above their bargaining propensity among all workers. Thus the role of the option to keep the current job when considering a new job opportunity in influencing the wage through bargaining is substantial, especially among more educated, problem-solving workers. The recent attention to the economics of on-the-job search is fully merited, in light of these findings.

Job-ladder models, such as Hagedorn and Manovskii (2009), stress the importance of the wage at one job that can be retained in negotiating with a prospective new employer. The models typically assume that the option to keep the earlier job was available for any job-to-job transition that is observed without intervening unemployment. With our data, we can take a different approach by asking if the current wage is higher among those who retained the earlier option against those who did not. The first set of workers are at least one step up the job ladder whereas the second set must be at the bottom. To investigate this, we estimate an equation for the median wage (using quantile estimation) with all of the variables in our descriptive models except the job characteristics, plus a dummy variable for those who answered that they could have retained their earlier jobs. We found that those with that advantage had a wage $\$ 2.07$ per hour higher than otherwise similar workers without the advantage, with a bootstrap standard error of $\$ 0.71$. The evidence unambiguously supports the hypothesis of a job ladder.

Table 6 describes the answer to the question, "Did your [current/most recent] employer learn how much you were making in your previous job before making you your job offer?" Knowledge of earlier pay is useful to the employer in cases where the possibility of bargaining influences the wage. The likelihood of a yes answer is 48 percent in the base case. Respondents with other characteristics varied only a small amount from this value. As expected, employers learned earlier pay less frequently for union members and for government jobs, but the difference is small.

The finding that many employers made an effort to learn earlier pay rates gives some further support to the hypothesis that wage posting is not the dominant mode of wage formation.

\section{Evidence on Bargaining and Heterogeneity}

As we discussed earlier, dispersion should be higher among workers who bargained relative to those who accepted a posted wage, within a category of workers defined by observed and 


\begin{tabular}{|c|c|c|}
\hline & \multicolumn{2}{|c|}{ Employer knew previous pay } \\
\hline & $\begin{array}{c}\text { Probability, } \\
\text { percent }\end{array}$ & $\begin{array}{c}\text { Difference } \\
\text { from base } \\
\text { case }\end{array}$ \\
\hline Base case & $\begin{array}{l}48 \\
(8)\end{array}$ & \\
\hline African-American & $\begin{array}{c}37 \\
(10)\end{array}$ & $\begin{array}{l}-11 \\
(7)\end{array}$ \\
\hline Latino/a & $\begin{array}{c}47 \\
(10)\end{array}$ & $\begin{array}{l}-1 \\
(6)\end{array}$ \\
\hline Woman & $\begin{array}{l}52 \\
(7)\end{array}$ & $\begin{array}{c}5 \\
(4)\end{array}$ \\
\hline Not HS graduate & $\begin{array}{c}42 \\
(11)\end{array}$ & $\begin{array}{l}-5 \\
(9)\end{array}$ \\
\hline Some college & $\begin{array}{l}41 \\
(7)\end{array}$ & $\begin{array}{l}-7 \\
(5)\end{array}$ \\
\hline College graduate & $\begin{array}{l}44 \\
(8)\end{array}$ & $\begin{array}{l}-3 \\
(6)\end{array}$ \\
\hline Professional training & $\begin{array}{l}49 \\
(8)\end{array}$ & $\begin{array}{c}1 \\
(7)\end{array}$ \\
\hline Union member & $\begin{array}{l}43 \\
(9)\end{array}$ & $\begin{array}{l}-5 \\
(6)\end{array}$ \\
\hline Government job & $\begin{array}{l}43 \\
(9)\end{array}$ & $\begin{array}{l}-5 \\
(6)\end{array}$ \\
\hline Non-profit job & $\begin{array}{l}48 \\
(9)\end{array}$ & $\begin{array}{c}0 \\
(5)\end{array}$ \\
\hline Senior & $\begin{array}{l}50 \\
(16)\end{array}$ & $\begin{array}{c}3 \\
(15)\end{array}$ \\
\hline Knowledge worker & $\begin{array}{l}52 \\
(8)\end{array}$ & $\begin{array}{c}5 \\
(10)\end{array}$ \\
\hline Blue collar & $\begin{array}{l}42 \\
(8)\end{array}$ & $\begin{array}{l}-6 \\
(9)\end{array}$ \\
\hline Recent job loser & $\begin{array}{l}48 \\
(8)\end{array}$ & $\begin{array}{c}0 \\
(2)\end{array}$ \\
\hline
\end{tabular}

Note: Bootstrap standard errors in parentheses.

Table 6: Probability that the Employer Learned Previous Pay before Making Job Offer 
verifiable characteristics. Theory suggests that wages will be higher for workers who bargain. We examine these predictions in this section.

We consider the distribution of the wage, $w$, conditional on a dummy variable $b=1$ for a worker who bargained and 0 if not. This distribution varies by observed characteristics $x$. We write the distribution as $F_{b}(w ; x)$, so $F_{0}(w ; x)$ is the distribution of $w$ among nonbargainers and $F_{1}(w ; x)$ the distribution among bargainers. We expect that the dispersion of $F_{1}(w ; x)$ will exceed that of $F_{0}(w ; x)$-wage dispersion will be greater among the bargainers than the non-bargainers.

We measure the distributions $F_{b}(w ; x)$ by quantile estimation. This method finds values $w_{i, b}(x)$ such that $F_{b}\left(w_{i, b}(x)\right)=q_{i}$ for a set of probabilities $q_{i}$. We take these to be deciles, so $q_{i}=i / 10$ for $i=1, \ldots, 9$. If the theoretical proposition is correct that dispersion is greater with bargaining, then dispersion measures such as $w_{9, b}-w_{1, b}$, the spread between the 9 th and 1st deciles, should be greater among the bargainers, $b=1$, than among the non-bargainers. See Koenker and Hallock (2001) for a discussion of quantile estimation.

We take the quantile functions to be linear in the characteristics:

$$
w_{i, b}(x)=\gamma_{i, b} x
$$

Of course, we choose the variables $x$ to be nonlinear functions, such as dummy variables for categories, of the actual measures from our survey.

Figure 2 compares the distribution of wages among non-bargainers, on the left, and bargainers, on the right. These are the overall marginal distributions over the characteristics $x$, computed directly from the wage data without quantile estimation. The shading in the vertical bars designates the deciles of the distribution, from the first to the ninth. The dispersion of wages is substantially higher among the bargainers, in line with the theory. And the median of wages is higher among bargainers, again in line with theory. The evidence from the raw dispersion of wages is far from dispositive, however, because the theory deals with dispersion conditional on the observed characteristics of job applicants. Education is the most salient of those characteristics and unquestionably an observed characteristic that plays an important role in screening workers.

Figure 3 repeats the comparison of the distribution of wages, now in a setting that standardizes for demographics and education, using quantile estimation. It shows the distribution of the wage of a white male with a high-school education but no college. We fit the distribution to all of our data, using quantile estimation at 9 deciles, then calculate the implied 


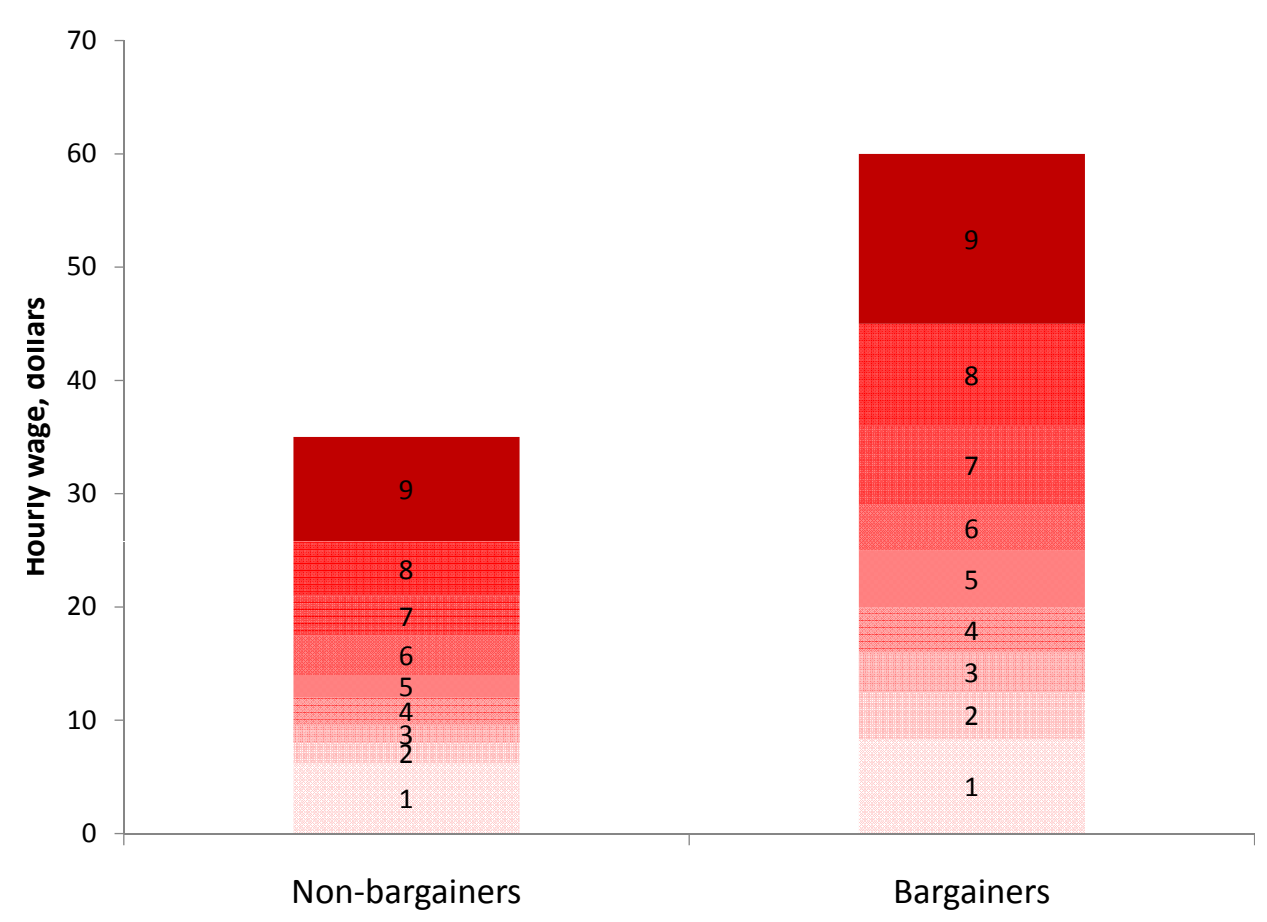

Figure 2: Distributions of Wages among Non-Bargainers and Bargainers

wages at the deciles, as displayed in the figure. Because bargaining is more common among better-educated workers, wage heterogeneity is smaller after conditioning on education. The dispersion remains higher among bargainers and so is the difference between median wages in the two groups.

In addition to the specification illustrated in Figure 3, we also consider a more restricted specification in which the characteristics $x$ determine the medians of the two distributions in an unrestricted way, but that the only difference in dispersion around the median is related to bargaining and not to the $x$-variables. To measure the difference in wage dispersion between the two groups for that assumption, we find the quantiles of the wage centered on the median; that is, we tabulate the deciles of the variables $w_{i}-m_{b_{i}}\left(x_{i}\right)$, where $w_{i}$ is worker $i$ 's wage and $m_{b_{i}}\left(x_{i}\right)$ is the median estimated for the worker's characteristics $x_{i}$ and bargaining dummy $b_{i}$.

Table 7 shows the results of these calculations. The left column shows the difference in the inter-decile range between bargainers and non-bargainers and the right column shows the differences in the median wage. In all cases we show the bootstrap standard errors of the differences. The top line examines the raw data on hourly earnings. The inter-decile range is $\$ 23$ per hour greater among bargainers than among non-bargainers and the median 


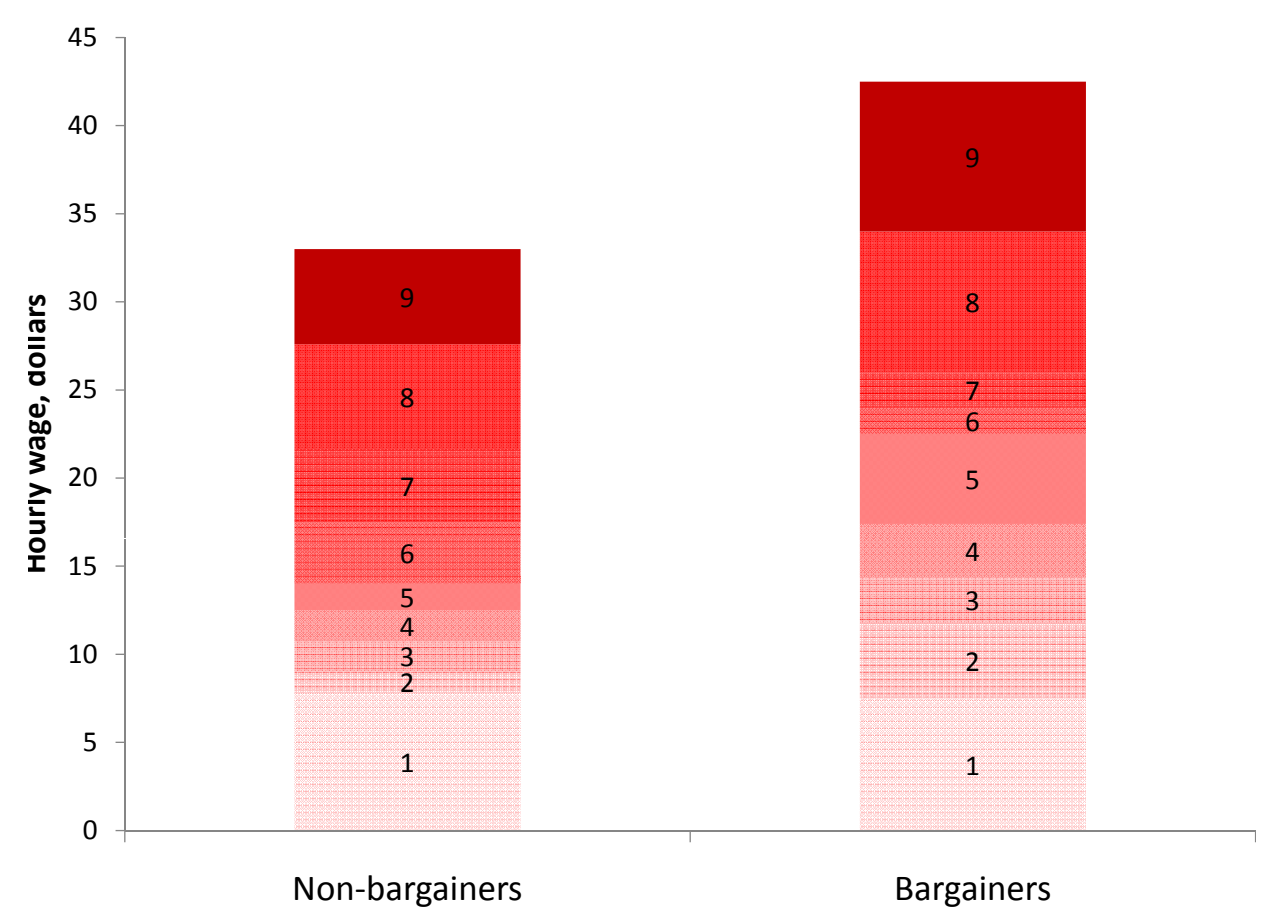

Figure 3: Distributions of Wages among Non-Bargainers and Bargainers, for White Male High-School Graduates

wage is $\$ 11$ per hour greater. The results confirm that the dispersion among bargainers is substantially higher and that this finding cannot be the result of sampling error alone.

The second line of the table shows the results of the more restricted specification in which demographics and education (the African-American, Latino/a, sex, and education dummy variables) affect the median wage but not the dispersion around the median. The difference in the dispersion of the raw wage around the fitted median between bargainers and nonbargainers is a little under $\$ 17$ per hour, with a bootstrap standard error of just over $\$ 3$ per hour (the bootstrap procedure takes full account of the two step estimation). Again, the evidence in favor of higher dispersion among bargainers is statistically unambiguous. The difference between the median hourly wages of bargainers and non-bargainers falls to $\$ 8$ with the adjustment, but the difference remains substantial in economic terms and statistically unambiguous. We conclude that there is strong evidence that workers who bargain earn higher wages, after considering that higher education raises both the level of wages and the likelihood of bargaining. Of course, the conclusion rests on the hypothesis that the demographic and education variables account for all the differences in wages that are correlated with bargaining. We are inclined to believe that part of the large advantage found here for 


\begin{tabular}{|c|c|c|}
\hline \multirow[b]{2}{*}{ Adjustments for demographics and education } & \multicolumn{2}{|c|}{$\begin{array}{c}\text { Measure of difference between bargainers and non- } \\
\text { bargainers }\end{array}$} \\
\hline & $\begin{array}{l}\text { Dispersion: Difference } \\
\text { between } 9 \text { th and 1st } \\
\text { decile wage, dollars per } \\
\text { hour }\end{array}$ & $\begin{array}{l}\text { Level: Median, dollars } \\
\text { per hour }\end{array}$ \\
\hline Without adjustment for demographics and education & $\begin{array}{l}23.00 \\
(3.50)\end{array}$ & $\begin{array}{l}11.00 \\
(1.20)\end{array}$ \\
\hline $\begin{array}{l}\text { With adjustment for demographics and education in median wage } \\
\text { but not in dispersion, measured for white male high-school } \\
\text { graduates }\end{array}$ & $\begin{array}{l}16.67 \\
(3.26)\end{array}$ & $\begin{array}{c}8.17 \\
(2.29)\end{array}$ \\
\hline $\begin{array}{l}\text { With adjustment for demographics and education in median and } \\
\text { disperson, measured for white male high-school graduates }\end{array}$ & $\begin{array}{c}9.68 \\
(6.26)\end{array}$ & \\
\hline
\end{tabular}

Table 7: Differences in Wage Distributions between Bargainers and Non-Bargainers, for White Male High-School Graduates

bargainers is the result of the factors discussed earlier in the paper that point in the direction of an advantage, but recognize that part of the large difference we find may be the result of selection factors unrelated to those factors.

The bottom line of Table 7 shows the difference in the inter-decile range for our base case when the entire distribution is taken to depend on the demographic and education variables, not just the central tendency. The difference in the inter-decile range is now somewhat below $\$ 10$ and its standard error is above $\$ 6$. Contrary to the assumption in the middle line of the table, some of the difference in dispersion between bargainers and non-bargainers disappears when the measure is standardized for the differing compositions of the two groups as measured by the demographic and education variables. The evidence remains favorable to the hypothesis that wage heterogeneity is higher among bargainers, but sampling variation is substantially higher and the measured effect is smaller. The large increase in the standard error in moving from the second line of the table to the third arises from the quantile estimation of the way that the characteristics $x$ influence the dispersion.

We intend our examination of wage dispersion mainly to validate the survey's measure of bargaining. Because posted wages inherently have less dispersion than bargained wages, no matter what governs employers' choices to post wages, we cannot claim to have validated a theory of when posting occurs. Apart from the characteristics that we and presumably 
employers observe, we do not measure the remaining differences in skills among workers who appear identical in terms of those characteristics, whereas the theory of the choice between posting and bargaining considers exactly those differences.

\section{Conclusions}

The two leading models of individual wage formation are both important in the labor market of the United States. Between a quarter and a half of workers hold jobs that were filled with posted wages. Jobs held by women and by people with little education are more likely to have been posted-wage positions. College graduates and those with professional training are rather unlikely to hold posted-wage jobs. Posted wage jobs are also common in the government and union sector.

The evidence suggests that most of the remaining workers do not face posted wages but could make a counteroffer that an employer could not resist considering. About a third of workers report explicit bargaining over pay. From bargaining theory, it is reasonable to infer that a fair number of others could have made a counteroffer, but employers, recognizing that possibility, make a satisfactory initial offer.

Wage-formation theory emphasizes the importance of the option that a job-seeker may have to retain a current job. The option is powerful in forcing a prospective employer to bid high to hire the worker. We find that 48 percent of workers in the base group had this option when they took their current jobs. On-the-job search is a central feature of the U.S. labor market. Job-ladder models emphasizing the bargaining power of a worker who already has a high-paying job in negotiating with a prospective employer are on the right track, especially among knowledge workers.

We find that about half of workers report that their new employers learned the workers' earlier pay rates before making them job offers. Employer interest in earlier pay is an indication against wage posting. Employers presumably use the information to formulate a satisfactory offer to workers who retain the option on earlier jobs. The information is not sufficiently widespread and employers are unable to commit to ignore counteroffers, else the U.S. labor market would suffer from the Diamond paradox. Instead, many workers appear to earn substantial Ricardian rents. 


\section{References}

Ausubel, Lawrence M., Peter Cramton, and Raymond J. Deneckere, Handbook of Game Theory, Elsevier, 2002.

Binmore, Ken, Ariel Rubinstein, and Asher Wolinsky, "The Nash Bargaining Solution in Economic Modeling," RAND Journal of Economics, Summer 1986, 17(2), pp. 176-188.

Burdett, Kenneth and Dale T. Mortensen, "Wage Differentials, Employer Size,and Unemployment," International Economic Review, May 1998, 39 (2), 257-273.

and Kenneth L. Judd, "Price Dispersion," Econometrica, July 1983, 51 (4), 955-969.

Butters, Gerard R., "Equilibrium Distributions of Sales and Advertising Prices," Review of Economic Studies, October 1977, 44 (3), 465-491.

Christiano, Lawrence J., Martin Eichenbaum, and Charles L. Evans, "Nominal Rigidities and the Dynamic Effects of a Shock to Monetary Policy," Journal of Political Economy, 2005, $113(1), 1-45$.

Diamond, Peter A., "A Model of Price Adjustment," Journal of Economic Theory, 1971, 3, $156-168$.

__ "Wage Determination and Efficiency in Search Equilibrium," Review of Economic Studies, April 1982, 49 (2), 217-227.

and Eric Maskin, "An Equilibrium Analysis of Search and Breach of Contract, I: Steady States," Bell Journal of Economics, 1979, 10, 282-316.

Ellingsen, Tore and Åsa Rosén, "Fixed or Flexible? Wage-Setting in Search Equilibrium," Economica, 2003, 70, 233-250.

Groves, Robert M. and Emilia Peytcheva, "The Impact of Nonresponse Rates on Nonresponse Bias: A Meta-Analysis," Public Opinion Quarterly, 2008, 72 (2), 167-189.

Hagedorn, Marcus and Iourii Manovskii, "Spot Wages over the Business Cycle?," October 2009. Department of Economics.

Hall, Robert E., "Employment Fluctuations with Equilibrium Wage Stickiness," American Economic Review, March 2005, 95 (1), pp. 50-65. 
— and Edward P. Lazear, "The Excess Sensitivity of Layoffs and Quits to Demand," Journal of Labor Economics, 1984, 2 (2), 233-257.

and Paul R. Milgrom, "The Limited Influence of Unemployment on the Wage Bargain," American Economic Review, September 2008.

Koenker, Roger and Kevin F. Hallock, "Quantile Regression," Journal of Economic Perspectives, Autumn 2001, 15 (4), 143-156.

McCall, John J., "Economics of Information and Job Search," Quarterly Journal of Economics, February 1970, 84 (1), 113-126.

Menzio, Guido, "A Theory of Partially Directed Search," Journal of Political Economy, 2007, 115 (5), 748-769.

Michelacci, Claudio and Javier Suarez, "Incomplete Wage Posting," Journal of Political Economy, 2006, 114 (6), 1098-1123.

Mortensen, Dale T., "Specific Capital and Labor Turnover," Bell Journal of Economics, Autumn 1978, 9 (2), 572-586.

— Wage Dispersion: Why Are Similar Workers Paid Differently?, Cambridge, Massachusetts: MIT Press: Zeuthen Lecture Book Series, 2003.

_ and Christopher Pissarides, "Job Creation and Job Destruction in the Theory of Unemployment," Review of Economic Studies, 1994, 61 (0), pp. 397-415.

Moscarini, Giuseppe and Fabien Postel-Vinay, "The Timing of Labor Market Expansions:

New Facts and a New Hypothesis," NBER Macroeconomics Annual, 2008, pp. 1-51.

Pissarides, Christoper A., Equilibrium Unemployment Therory, second ed., Cambridge, Massachusetts: MIT Press, 2000.

Rogerson, Richard and Robert Shimer, "Search in Macroeconomic Models of the Labor Market," in Orley Ashenfelter and David Card, eds., Handbook of Labor Economics, Vol. 4, Elsevier, 2012, forthcoming.

__ _ _ a and Randall Wright, "Search-Theoretic Models of the Labor Market: A Survey," Journal of Economic Literature, December 2005, 43, pp. 959-988. 
Shimer, Robert, Labor Markets and Business Cycles, Princeton, NJ:, Princeton University Press, 2010.

Stigler, George J., "The Economics of Information," Journal of Political Economy, 1961, 69 (3), 213-225.

, "Information in the Labor Market," Journal of Political Economy, 1962, 70 (5, Part 2), 94-105. 